\title{
ASPECTS OF CHILD EVANGELISM AND YOUTH MINISTRY IN SOUTH AFRICA IN THE POSTMODERN CONTEXT OF GLOBALISM, PLURALISM AND CURRENT SCIENTIFIC KNOWLEDGE
}

\author{
Annette Evans \\ Postgraduate School \\ University of the Free State
}

\begin{abstract}
After the demise of the Apartheid regime the Religious Instruction syllabus of the Christian National Education system was changed to 'Religious Education'. The new syllabus requires that all religions should be taught in schools. Compounding the difficulties of pluralism, the global postmodernist cultural context has promoted cognitive dissonance in young Christians in that Christianity is now only one option among other religions claiming the same character of truth and demanding the same adherence. Can traditional approaches to child evangelism and youth ministry still be relevant in the context of scientific education and pluralism in South Africa? To explore this question three recent apparently widely-diverging publications are consulted: 1) Jansen (2009), 'Knowledge in the blood. Confronting race and the Apartheid past'; 2) Claassen \& Gaum (2012), 'God? Gesprekke oor die Oorsprong en Uiteinde van Alles'; 3) Gericke (2013), 'A philosophical clarification of the axiological assumptions behind the concept of goodness in Genesis 1'.
\end{abstract}

Key Words: Child Evangelism; South Africa; Postmodernism; Pluralism; Scientific Education

\section{Introduction}

'It is not so important that many should be as good as you, as that there be some absolute goodness somewhere; for that will leaven the whole lump' (Thoreau 1848, 1972:240).

Sixteen years ago Friedrich Schweitzer (1999:69) recognised that if Christian education is to face up to the challenges of our present and our future it is necessary to clarify the ways in which global issues are important for Christian education and youth ministry. In South Africa the Apartheid baggage complicates the issue. Up until 1994 the Apartheid leaders in South Africa were wielding a racially discriminatory political power justified by an ideologically warped version of Christianity. In 1994 the representatives of this minority group with first-world European ancestry were forced, in the name of democracy, to share, and ultimately to yield power, to a so-called third-world majority. Today the remaining loyal products of Apartheid's Christian National Education system are trying to reverse the trend which has resulted in a dwindling membership of the erstwhile politically mighty Dutch Reformed Church. Only now, in the interface between these vastly different cultural backgrounds, are the new challenges for youth ministry being recognised. ${ }^{1}$

Evans 2012:84; 2013:315; 2014a; 2014b. 
Compounding the challenges of pluralism in South Africa are two underlying global problems: varying degrees of fundamentalism on the one hand, and the fact that religion is no longer as culturally central as it was until the onset of modernity. Erickson (1999:16-18) distinguishes between 'hard' and 'soft' modernism: in 'hard' modernism knowledge is restricted to what can be known through reason and experience, excluding any sort of intuition, and the scientific method is considered the only way to discover truth - it is reason that defines the relations in society, and ambivalence and secularization is the order of the day. Soft modernism still shares with premodernism the belief that integrative metaphysical schemes or world views can be constructed, but because modernity regards intuition as illogical, intuitive knowledge is not considered real, thus supernaturalism of any kind is excluded. The problem for Bible-based religion is obvious, because supernaturalism permeates the Bible. The question must be asked: can traditional approaches to child evangelism still be relevant ${ }^{2}$ In an attempt to find answers this paper considers three apparently widely diverging recent publications: 1) Jansen (2009), Knowledge in the blood. Confronting race and the Apartheid past; 2) Claassen \& Gaum (2012) God? Gesprekke oor die Oorsprong en Uiteinde van Alles; 3) Gericke (2013), A philosophical clarification of the axiological assumptions behind the concept of goodness in Genesis 1.

\section{The After Effects of the Former 'Christian National Education' System South Africa's new Pluralistic Society}

Jansen (2013:265) wonders why nobody writes about the power of indirect knowledge, the 'knowledge in the blood' that he perceives to be hampering the second generation of Apartheid's rulers:

...it leaves them stunted in their social, moral and emotional development in the same way Apartheid distorted their parents' sense of themselves within the human community - a distortion transmitted to their children (Jansen 2013:265).

The above observation made during Jansen's term as Dean of the Education Faculty at the University of Pretoria (started in June 2000), is given current credence and deepened by interviews with prominent Afrikaners, familiar to the general public, reported in Claassen \& Gaum (2012). The twenty-four interviewees come from varied Afrikaner backgrounds, but they are all seriously committed to South African society. Twelve are professing Christians; the other twelve are either agnostic or outright atheists. Of the latter twelve, three quarters describe their childhood experience of Christianity during the Apartheid years as negative or counterproductive. ${ }^{3}$ Several interviewees in this group describe the authoritarian, dogmatic type of Protestantism in which questioning was unacceptable. Jansen's perception that the parents had a distorted sense of themselves within the human community has recently been verbalised by Pieter Joubert who suggests: 'die vraag wat Suid-Afrikaners hulself vandag moet afvra, is of hul standpunte met die moraliteit en etiek

2 For what is meant by 'traditional approaches to child evangelism' the worldwide organization Child Evangelism Fellowship (CEF) based in the USA, is a good example. In their approach to young children CEF start with God as perfectly good and as creator of a perfect world. By way of 'The Fall' they explain that Adam's disobedience introduced original sin and death into the world, sin thereby being imputed to all of humankind, and only forgivable through faith in the atonement wrought by Christ's suffering and death on the cross. For contestation of this approach, see Evans (2012:87;90-93). For subsequent development of the argument see Evans 2013, 2014a, 2014b.

3 For instance see Willemien Brümmer's (2012:202-204) description of her torment when exposed to wellmeant child evangelism. The others are: Jurie van den Heever; Dave Pepler; Antjie Krog; Lizette Rabe; Abel Pienaar; Hans Pietersen; Christi van der Westhuizen. 
van ' $n$ vinnig veranderende wêreld strook. ${ }^{4}$ He stresses the need to be sensitive to our own psychological orientation and stereotypes.

After the fall of the Apartheid regime the official ideology that led to the establishment of Christian National Education, positing that Christianity is the only correct way of life, could no longer be part of schooling (Mkhatshwa 1998:xv-Xvi). In the new pluralistic state, religion in education could no longer be thought of in terms of faith-nurturing or religious instruction, or biblical studies, because in the exclusivist approach of Christianity any other religions could be seen only in terms of threat and conflict. Thus the Religious Instruction syllabus was changed to 'Religious Education'. The new syllabus requires that all religions should be taught in schools - there should be active and constructive interaction between all religious traditions and organizations. ${ }^{5}$ Christianity is only one option among others claiming the same character of truth and demanding the same adherence (Yu 2013). Chilton \& Neusner's (1995:xii) definition of religion explains why, in a pluralistic society, religion has the potential to be a divisive factor, and has indeed proved to be so - terribly - in countries where fundamentalism is rife: 'a religion sets forth a theory of the social order, for which divine or supernatural warrant is claimed, that defines what people are to do and explains how and why they are to do it: a way of life, a world view, and a definition of the social entity ... that embodies the way of life and appeals in explanation to the world view.'

Adding to the difficulty of pluralism, the postmodernist cultural context, with its definition of truth as relative to cultural context, has promoted cognitive dissonance in the youth with regard to Christian education. Over the past twenty years it has become apparent that Religious Education is not contributing to the real nation building required in South Africa. Although there is a spiritual hunger, and receptivity of evangelism in young children is effective to some extent, the retention and continued practice of Christianity as children grow older, is largely lost. A survey presented by Barna Research Group reports the fruitfulness of working with young children from ages 5 through 13, reporting that this age group has a $32 \%$ probability of accepting Christ as their Saviour, but young people from the ages of 14 through to 18 have just a $4 \%$ likelihood of doing so. ${ }^{6}$ The reason seems to be mainly one of cognitive dissonance as children grow older, partly because of exposure to pluralism, but it also has to do with the lack of integration of scientific advances into their world view. I would suggest that to facilitate a workable Christian faith plus a real nation building ethos a two-pronged approach is required: firstly, a more creative attitude towards the potential benefits of postmodernism and pluralism; and secondly, a more enlightened and coherent conception of the biblical account of creation in order to take into account the modern science of evolution and its precepts.

4 Statement made at the North West University Potchefstroom Campus on 6 March 2014, reported by Susan Celliers.

5 As opposed to 'the suffering under a 'tyranny of religion', (Du Toit \& Kruger: 1998:vii;viii). In our South African 'rainbow nation', pluralism is supposed to be treasured and requires respect between the different elements of society. Mkhatshwa (1998:xiii;xv;xvi) points out that to be fair, although in South Africa religion has been misused to divide and oppress, it has also served as inspiration towards creating and sustaining a society in which all religious persuasions would be able to function freely.

6 Information obtained from a current brochure of Child Evangelism Fellowship Inc. (CEF), a world-wide organization founded in the USA in 1937. 


\section{The First Prong: Potential Benefits of Postmodernism, Pluralism and Globalism}

As early as World War One cultural critics observed that there was growing 'disillusionment with modernity's championship of rationality, individual autonomy, and technology' (Phan 2007:2). Consequently the multivalent term postmodernism arose. Postmodernism has observed that the text of life is constantly in a process of change and thus needs ongoing interpretation because there are no fixed truths and values in life - it is no longer possible to find one underlying truth or value system for society. Postmodern epistemology necessitates respect for, and celebration of particularity and 'otherness' in all dimensions of human life, from race and ethnicity to gender, religion and culture (Phan 2007:3). Because all knowing and speaking are done from a particular perspective, and each perspective is equally true or valuable, postmodernism maintains an incredulity towards meta-narratives. ${ }^{7}$ The postmoderm philosophers Lyotard, Heidegger and Derrida understand language as a metaphor for life as an ongoing and never-ending hermeneutic process. Janse van Rensburg $(2000: 26 ; 34)$ points out that none of these philosophers are Christians, and none of their discourses 'make it possible to accommodate the truth of the Bible as a universal truth in any way.' However, philosophy does indicate to us what is happening to culture. The threat to the cause of Christianity that many see in postmodernism is that it rejects any notion of unity in discourse, or any effort to proclaim absolute truth (Yu 2013; Erickson 1998:20; Janse van Rensburg 2000:34). Schweitzer (1999:7073) points out that we need to see that globalization affects and redefines the local, and we need to change our perspective in dealing with such international influences as the media as carriers of international youth culture. For instance, he refers to feedback from a young woman who states that 'God, as she perceives him to be presented by the church, remains alien to her experience'. Schweitzer refers to another sixteen-year-old who can only go so far as to say she believes 'in faith', thus making faith 'a purely subjective act without any content.' Christian educators need to take note and take up the creative challenge of finding a way to translate biblical culture into the values of contemporary culture (Gold 2004:97;115). This may mean changing the style of presentation of the gospel (Erickson 1998:152).

These challenging aspects of globalism and postmodernism should not be allowed to overshadow the positive benefits. After all, the idea of ecumene, 'the whole world', has important roots in the New Testament, and it clearly includes issues of justice, peace and ecology (Schweitzer 1999:69). It is increasingly being realised that the content of proclaiming God's salvation must extend beyond Christianity toward other faiths and religions. Steyn (1998:83) pinpointed the basic problem fifteen years ago: 'The question of confusing our children in multi-religious education revolves around truth claims.' She foresaw that multi-religious education could perhaps do more harm than good in that the children could become confused about their own faith orientation, but on the other hand she recognised that 'multi-religious education uncovers the common humanity that underlies the plurality of the people of this country' (Steyn 1998:ix;x). Morality cannot be equated with religion (Mkhatshwa 1998:xvi), but McGurk (1998:130) claims that in the overall socialization process in the schools, education as a community responsibility has a "very

The phrase was coined by Lyotard in 1984 . The term meta- or grand-narrative refers in postmodernism to a comprehensive explanation, a narrative about narratives of historical meaning which offers a society legitimization of an overarching master idea. 
real practical theological dimension in the communication of the essentially moral and religious character of human community.'

As with modernism, Erickson (1999:19;20) makes a nuanced distinction between 'hard' and 'soft' postmodernism. One of the helpful aspects of soft postmodernism is that it rejects the extremes of modernism and recognises the value of intuition in acquiring knowledge: 'the presence of soft postmodernism is encouraging to Christians. It opens the door for believers to contend for the truth of the Christian faith, in contrast to a secular world that formerly excluded any faith of this type' (Lakeland 1997:112). Lakeland sees 'a lesson for Christianity in postmodernism ... there are many alternative versions of reality, many different ways of being in the world'. He stresses that although it is necessary to choose one way, it is important to stop there, and 'not proceed to extravagant claims about the exclusive superiority of the Christian tradition.' Brueggeman (1997:112) has also observed that we need to recognise that 'Absolutist claims for the Christian gospel are not only practically destructive, but theologically inimical to the gospel itself.' Prakash (2005:3) recognises that Christian mission in its narrow form can be containing and rigid, and thus contrary to the precepts of postmodernism, but in its truly universal sense the very nature of Christian Mission is global; Christianity should be all embracing and flexible, so that it can permeate all sections of society. Nouwen (1980:82) claims that 'there are just as many ways to be a Christian as there are Christians.' He blames the exclusivity and dogmatism with which Christianity has maintained its unique identity for the result 'that many find religious education boring, superfluous, and unnecessary, and they complain that it creates fear instead of joy, mental imprisonment instead of spiritual freedom.' His view concurs with Schweitzer's experience that many students do not care for religious instruction mainly because their own life experience is hardly touched.

The challenge lies in 'maintaining a Christian vision that would not exclude or repress others but would also make a positive contribution to the diversity-in-unity of our modern scientific, technological and global culture' (Lakeland 1997:113). Lakeland (1997:37;38) points out that 'contemporary theology has paid too little attention to the shift in perspective in the scientific community.' He is referring to relativity theory, the uncertainty principle, quantum mechanics, and chaos theory, and suggests that what postmodern science uncovers is a world in which mystery is real. The benefit of postmodernity is the acceptance of uncertainty and mystery. I would suggest that in our rapidly changing world and social order education towards a general spiritual development could be the truly unifying element in our differing ways of being human. Spiritual development is defined by Roelkepartain et al. (2006:5) as 'a developmental wellspring out of which emerges the pursuit of meaning, connectedness to others and the sacred, purpose, and contributions, each and all of which can be addressed by religion or other systems of ideas and belief.' Benson (2003:204) elaborates: 'Spiritual development is the process of growing the intrinsic human capacity for self-transcendence, in which the self is embedded in something greater than itself, including the sacred. It is the developmental 'engine' that propels the search for connectedness, meaning, purpose and contribution.' In such a direction for education, the importance of coherence between biblical concepts and modern science must be recognised and integrated into a Christian world view. It is overdue for Christian education to achieve coherence between the description of God's creation in Genesis 1 and 2 as 'good/very good' and the scientific reality of evolution as the means of creation, with all its natural disasters, waste and suffering. 


\section{The Second Prong: Coherence between Scientific Knowledge and Biblical Values as World View}

Children's Bibles almost always start with Adam and Eve in the garden of Eden, accompanied by the traditional explanation of 'the fall' and 'original sin', which more often than not eventually results either in a crippling sense of guilt, or in cognitive dissonance. The theologian John Haught $(2008: 127 ; 148)$ helps to make the necessary paradigm shift with his observation that 'original sin' can still express meaningfully the sense of humanity's estrangement from the deity, but 'the 'ideal' world is the enlivening new creation yet to come, not a once perfect world to which we now seek nostalgically to return.' Gericke's $(2013: 213 ; 218)$ philosophical clarification of the relevant presuppositions in Genesis 1 concerning the nature of goodness is helpful in this regard. He approaches the task by asking, in the Ricoeurian sense, 'what did the word 'good' signify within the world in the text ... what was presupposed regarding the meaning of the concept of goodness in this context?' ('Paul Ricoeur speaks of the theologian as a hermeneut, whose task is to interpret the multivalent, rich metaphors arising from the symbolic bases of tradition so that the symbols may 'speak' once again to our existential situation' (Overzee 1992:4)). Along the route of philosophical reasoning Gericke (2013:210-225) is able to describe 'elements and aspects of the folk theory of value presupposed by the character of Elohim' to arrive at the insight that Genesis 1 'of necessity ... will contain folk-axiological assumptions that are nascent and a folk-theory of value which remains unstated.' He points out (2013:220-222) that 'Goodness' is always relative to an agent, and in this case the agent Elohim's valuation is described biblically as done from a subjective perspective - it is experienced as good, and therefore assumed to be good. ${ }^{8}$ Thus Elohim's positive theory is based on the assumption that there could be one intrinsic value, i.e. 'goodness', but most of the values related to the good of creation are assumed to be conditional, since Elohim assumes a 'satisficing' conception rather than a 'maximising' one - the creation of the world is 'good enough' rather than 'best'. In this way Gericke arrives at a perspective that can to some extent be brought into coherence with what we know today of evolution as the scientific explanation of how creation has evolved: even the Priestly version of the flood comes into some degree of coherence with evolution in that things are not assumed to be perfect and might need to be destroyed later on. ${ }^{9}$

\section{Discussion}

In examining Christian Mission in India, Prakesh (2005:5) saw the first principle of an appropriate response to the impact of globalisation to be attuned to the changing times, and to respond in a way which is appropriate. With respect to religion in schools Du Toit \& Kruger (1998:x) state the ideal: when the specific problem of 'comparative ethics' is addressed, teachers need to do justice to the faith of others without denying their own - not loss of religious integrity, but gain in the quality of religious integrity. Phan (2007:7) claims that human knowledge is obtained in a 'serious and thoughtful give-and-take of mutual learning and teaching, in a respectful and humble conversation with the tradition and the community of fellow seekers, in a word, in a genuine dialogue with the other ...' McGurk $(1998: 131 ; 133)$ sees the 'higher-order' values that will facilitate dialogue and movement within the school and society as a whole to be a vision incorporating the possibilities of the

The goodness is identified with some natural property or properties, therefore naturalistic.

For an explanation of the relation of this observation to that of the process of evolution, see Evans 2013. 
higher spiritual values. Such a 'correlative life-informing community' would effect the continuous emergence of the higher value in the other.' McGurk indicates the educational way with his concept of 'Interculturation': 'the experience of moving imaginatively into other cultures and faiths, then returning to one's own culture and faith with renewed insight and creativity, in order to share common higher-order universal values as a basis for mutual enrichment ... It is the process in which the students themselves become multicultural.'

\section{Conclusion}

In the context of pluralism, traditional approaches to child evangelism need to be adjusted if later cognitive dissonance of the youth is to be avoided, and coherence between Christianity and the realities of global postmodern culture, including current scientific knowledge, is to be achieved. In one of South Africa's greatest defining moments Nelson Mandela said 'My wish is that South Africans never give up belief in goodness.' Goodness is not the sole prerogative of Christianity. Interestingly, that there is hope for the new generation was recently reflected in Cape Town's morning daily, Die Burger, to the effect that we of the older generation sometimes do not understand the youth of today because they have developed a sensitivity for what is good and right, that we never had. ${ }^{10}$

\section{BIBLIOGRAPHY}

Ammerman, Nancy T, Marty, Martin E, Daloz Parks, Sharon, Schweitzer, Friedrich, Willimon, William 1999. Growing up Postmodern. Imitating Christ in the Age of 'Whatever'. Princeton: Institute for Youth Ministry, Princeton Theological Seminary.

Benson, PL, Roehlkepartein, EC, \& Rude, SP 2003, 'Spiritual Development in Childhood and Adolescence: Toward a field of enquiry.' Applied Developmental Science 7 (2003:204-212).

Brueggeman, Walter 1997. Theology of the Old Testament. Testimony, Dispute, Advocacy. Minneapolis: Fortress Press.

Cilliers, Susan 2014. 'Baie swart mense het nog onverwerkte trauma.' Die Burger, 8 March.

Chilton, Bruce \& Neusner, Jacob 1995. Judaism in the New Testament. Practices and Beliefs. London/New York: Routledge.

Claassen, George \& Gaum, Fritz 2012. God? Gesprekke oor die Oorsprong en Uiteinde van Alles. Cape Town: Tafelberg.

DJS 2014. 'Geestelike Waardes'. Die Burger, 8 March, 2014.

Du Toit, CW \& Krüger, JS (eds.) 1998. Multireligious education in South Africa. Problems and prospects in a pluralistic society. Pretoria: University of South Africa.

Du Toit, CW \& Kruger, JS 1998. 'Preface' in Du Toit \& Kruger, vii-xi. Erickson, Millard J 1999. (1998) Postmodernizing the Faith. Evangelical Responses to the Challenge of Postmodernism. Grand Rapids, Michigan: Baker Books.

Evans AHM 2012. "Evangelism of Young Children: Is an evolutionary understanding of 'Original Sin' possible?” OTE 25/1 (2012:84-99).

10 DJS Die Burger 8 March 2014. 
Evans AHM 2013. 'Interpreting the Bible for Children in coherence with evolution'. OTE 26/2 (2013:315-333).

Evans AHM 2014a. 'The Bible for children in a postmodern context: How do children form explanatory concepts?', Verbum et Ecclesia 35(1), Art. \#820, 7 pages. http://dx.doi.org/10.4102/ve.v35i1:820.

Evans AHM 2014b. 'Relevance Theory as an approach to interpreting the Bible for Children: The Lucan version of the Lord's Prayer as a test case', Verbum et Ecclesia 35(1), Art. \#1325, 6 pages. http//dx.doi.org/10.4102/ve.v35i1.1325.

Gericke, Jaco 2013. 'A philosophical clarification of the axiological assumptions behind the concept of goodness in Genesis 1.' Journal for Semitics 22/1:210-225.

Haught, John F 2008. God after Darwin. A Theology of Evolution. Boulder: Westview Press.

Jansen, Jonathan D 2013. Knowledge in the Blood. Confronting Race and the Apartheid Past. Cape Town: UCT Press. Reprint of 2009. Standford: Stanford University Press.

Janse van Rensburg, Johan 2000. The Paradigm Shift. An Introduction to Postmodern Thought and its Implications for Theology. Pretoria: Van Schaik Publishers.

Lakeland, Paul 1997. Postmodernity. Christian identity in a fragmented Age. Guides to theological enquiry. Minneapolis: Fortress Press.

Lyotard, Jean-Francois 1984. The Postmodern Condition: A Report on Knowledge. Minneapolis: University of Minnesota Press.

McGurk, NJ 1998. 'The Christian school in an integrated, pluralistic society: A South African experience.' In Du Toit \& Kruger, 23-133.

Mkhatshwa, S 1998. Opening Address. In Du Toit \& Kruger, xii-xix.

Nouwen, Henri JM 1980. Reaching Out. The Three Movements of the Spiritual Life (reprint 1976). London: Harper Collins Publishers.

Overzee, Anne Hunt 1992. The body divine: the symbol of the body in the works of Teilhard de Chardin and Rāmānuja. Issue 2 of Cambridge studies in religious traditions. Cambridge: Cambridge University Press.

Phan, Peter 2007. 'Evangelization in a Culture of Pluralism: Challenges and Opportunities'. Australian ejournal of theology 9 (March 2007). http://aejt.com.au/_data/assets/pdf_file/0006/378591/AEJT_9.1_Phan_Evangelizati on.pdf 2014. Accessed 1/2/2014.

Prakash, SJ Cedric 2005. The Impact of globalisation on Christian Mission in India. http://bocs.hu/india/cp-globalisation.htm accessed 29/01/2014.

Roelkepartain, Eugene C, Ebstyne King, Pamela, Wagener, Linda, M. Benson, Peter L. (Eds.) 2006. The Handbook of Spiritual Development in Childhood and Adolescence. London: Sage Publications.

Roelkepartain, Eugene C, Benson, Peter L, Ebstyne King, Pamela, Wagener, Linda M (eds.) 2006. 'Spiritual Development in Childhood and Adolescence: Moving to the Scientific Mainstream', in Roelkepartain et al. 1-16.

Schweitzer, Friedrich 1999. "Global Issues Facing Youth in the Postmodern Church", in Ammerman, Nancy T; Marty, Martin E; Daloz Parks, Sharon; PAGE NUMBERS? 
http://scriptura.journals.ac.za

Child, Youth Ministry in SA in Postmodern Globalism, Pluralism and Scientific Knowledge Context 9

Schweitzer, Friedrich; Willimon, William 1999 Growing up Postmodern: Imitating Christ in the Age of 'Whatever', 67-78. Princeton: Princeton Theological Seminary.

Steyn, HC 1998. 'Multireligious education: Confusion or appreciation?' in Du Toit \& Kruger, 78-100.

Thoreau, Henry David 1972. Walden and On the Duty of civil Disobedience. New York: The Macmillan Company. First printed 1854 and 1848.

Yu, Carver 2013.

http://www.christianexaminer.com/Articles/Articles\%20Oct10/Art_Oct10_20.html Accessed 31/01/2014. 